\title{
Pre-Print
}

Permission Granted to Authors to Post Online by

The Great Commission Research Journal.

\section{Innovativeness and Church Commitment: What Innovations Were Most Important During the Pandemic?}

Anna Covarrubias, David R. Dunaetz and Wendi Dykes McGehee Azusa Pacific University

\begin{abstract}
The COVID-19 pandemic created an unprecedented need for innovations in churches around the world. Organizational innovativeness, a precursor of successful innovations in organizational contexts, is rarely studied in churches. This study of American church attenders $(N=244)$ found that perceived innovativeness of churches (conceived of as the elements of a church's culture which promote innovation, specifically, creativity, organizational openness, future orientation, risk-taking, and proactiveness) was a very strong predictor of church commitment (conceived of as intentions to stay in the church, $r=.60, p<.001$ ). Of the moderators examined in this study (membership tenure, age of participant, church size, and gender), only gender moderated this relationship; the relationship between perceived innovativeness and church commitment was stronger for females than for males. This suggests that innovations that facilitated relationship development and relationship maintenance had the greatest impact on church commitment during the pandemic.
\end{abstract}

Gordon Penfold, Guest Editor 
Beginning in March 2020, a combination of general fear and government regulations forced churches in the United States and throughout the world to halt face-to-face meetings, whether for worship, teaching, evangelism, service, or fellowship. Such a disruption in church programs was unprecedented in recent memory and created a more urgent need for ministry innovation than these churches had ever previously experienced. Although the aftermath of the pandemic is not yet fully understood, some churches will likely withstand the pandemic more successfully than others (Rainer, 2020; Whitesel, 2020). Changes made within a church during the pandemic (via innovations such as moving small groups and youth ministries online) will likely be a major factor contributing to the longterm outcomes that the church will experience.

An important outcome of the pandemic that concerns virtually all churches is whether members will continue to be committed to their prepandemic church, will they leave the church to start attending elsewhere, or will they not return to church at all? This study explores whether perceived church innovativeness (the elements of organizational culture that promote innovations in a church; Ruvio et al., 2014) is related to commitment to one's church during the pandemic. Given that church members are often reputed for being resistant to change (Barna, 1993; Neighbour, 1973; Penfold \& Taylor, 2020), it is possible that innovativeness is viewed negatively by church members and decreases their commitment to the church as they see the old and familiar threatened by the new and unfamiliar. Yet it is also quite possible that innovativeness has a positive effect on church members, increasing their commitment to the church as they see the church respond creatively and effectively to the challenges faced during the pandemic.

\section{Organizational Innovativeness in Churches}

Organizational Innovativeness is an important concept actively studied in organizational psychology, management, and business, but is rarely studied in churches. The term innovation is derived from the Latin word novus "new." In organizational contexts, it can be defined as a new and beneficial process, idea, or product within a group, organization, or wider society (Choi \& Choi, 2014; Powell \& Pepper, 2018; Ruvio et al., 2014). From a theological point of view, innovations initiated by both God and humans are important. For example, for humans, innovation is an important aspect of worship (Psalm 96:1). Moreover, it is fundamental to Christ's redemptive work; when individuals place their faith in Christ, through God's work of regeneration, a new creation emerges and all is made new (2 Cor. 5:17), as will occur also with all of creation at Christ's 
return (Rev. 21:5).

Innovativeness, an aspect of an organization's culture, supports innovative processes over time and can be described as the willingness, capacity, and openness to innovate (Hult et al., 2004; Hurley et al., 2005; Powell \& Pepper, 2018; Ruvio et al., 2014). Innovativeness can be seen in the thinking of the apostle Paul when he speaks of a "great door for effective work" being opened (I Corinthians 16:9, NIV) and "an open door for our message" (Colossians 4:3, NIV). These passages reflect the heart of a God (as well as the Missio Dei) who desires the effects of the gospel to progress, expand, and grow.

Organizational Innovativeness has sometimes been viewed as the number of innovations an organization produces (Garcia \& Calantone, 2002; Salavou, 2004; Wang \& Ahmed, 2004). Others consider innovativeness to be an aspect of organizational culture reflecting a climate within an organization that is open, willing, and supportive of the continuous generation of ideas, products, or change (Hult et al., 2004; Hurley et al., 2005; Salavou, 2004; Wang \& Ahmed, 2004). Simply recognizing the need for innovation and integrating this need into the culture is likely to contribute to innovation (Van de Ven, 1986). In effect, an innovation is the product or idea that is generated while innovativeness is the culture that supports innovation and innovators.

Ruvio and colleagues (2014) have developed a five-dimensional model of organizational innovativeness. Rather than assuming that the number of innovations produced by an organization represents their innovativeness, this model describes five aspects of culture that characterize innovativeness: creativity, organizational openness, future orientation, risk-taking, and proactiveness.

\section{Creativity}

Woodman, Sawyer, and Griffin (1993) describe the end product of organizational-level and group-level creativity as "the creation of a valuable, useful new product, service, idea, procedure or process by individuals working together in a complex social system" (p. 293). While group creativity is not simply the sum of the individual group members' creativity, group composition, characteristics, and process factors contribute to group creativity (Woodman, Sawyer, \& Griffin, 1993). Antecedents to group creativity include leadership, cohesiveness, group composition, and group structure (King \& Anderson, 1990). Research around these factors suggests that creative outcomes are more frequently generated when the leadership is collaborative and democratic (in contrast to autocratic), the structure is less formal and mechanistic, and group 
members are characterized by cognitive and functional diversity (Woodman, Sawyer, \& Griffin, 1993). Similarly, creativity at the individual level (a necessary part of organizational creativity) depends on group and organizational culture which is influenced by how the social, contextual, and environmental characteristics of the group and organization interact with one another.

A potential hindrance to group creativity is groupthink (Janis, 1982). Groupthink characterizes decision-making when consensus and harmony are top priorities. With these priorities, group members discourage external influences and critical thought to enter the discussion, thus reducing the potential for creativity (Janis, 1982).

The concept of creativity is a central theme of the early chapters of Genesis describing the creation of the world. From there, this Creator of the world is revealed to be the God whom his people are to love and serve. Yet the creativity of God is not limited to the world as we now know it; it also characterizes his actions at the consummation of time, "For behold, I create new heavens and a new earth" (Is. 65:17, NASB).

\section{Organizational Openness}

Organizational openness is an aspect of organizational culture characterized by flexibility and adaptability in response to new ideas and changes (Ruvio et al, 2014; Hurlet et al., 2005). Flexibility and adaptability are most likely to occur when the need for new ideas and actions is recognized (Van de Ven, 1986). Organizational openness to a specific change consists of two parts (1) the willingness of the organization to support the new idea or change and (2) positive feelings of the employees concerning the potential consequences of the innovation (Wanberg \& Banas, 2000).

Although openness to false teaching and doctrine is strongly discouraged in the Bible (e.g., Gal. 1:6-9), openness to Spirit-led ecclesial changes characterizes much of the New Testament (e.g., the Jerusalem Council in Acts 15 and Paul's exhortations in his epistles). This need for openness to change continues today; Powell and colleagues (2012) found that the perception of a church's openness to innovation attracts newcomers and promotes the growth of the church.

\section{Future Orientation}

Rather than relying on past experiences to predict future success, a future orientation looks toward possibilities and envisions what may lie ahead (Ford, 2002). Vision casting, goal setting, and the creation of a culture that focuses on the future are precursors of innovation because they encourage 
creativity and outside-the-box thinking (Ford, 2002; Gavetti \& Levinthal, 2000). An organizational culture characterized by a future orientation paves the way for radical innovation (as opposed to incremental innovation) because vision casting and goal setting encourage people to think of the broadest range of possibilities rather than the gradual improvement of existing products, processes, and services (Christensen, 2013).

A biblical example of goal setting requiring outside-the-box thinking can be found in Mark 2:1-12 where a group of men brought their paralyzed friend to be healed by Jesus. After realizing that access to Jesus was not feasible because of a large crowd, they dug a hole in the roof of the building and lowered their friend to Jesus. Jesus, being impressed by their faith as expressed in their determination to reach their goal through an innovative technique, healed the man both physically and spiritually.

\section{Risk-Taking}

A culture of risk-taking is an important aspect of innovative organizations (Ruvio et al, 2014). Risk-taking can be defined as the degree to which organizations are willing to make commitments with unsure outcomes in attempting to realize their goals and vision (Caruana et al., 2002; Lumpkin \& Dess, 1996; Miller \& Friesen, 1978). Genuine risk includes the threat of a poor outcome (March \& Shapira, 1987), a threat that is unacceptable in many organizations and thus hinders innovation. Risk-taking organizations give permission to fail and encourage experimentation in order to promote creativity and innovation (Dykes, 2018; Kelley \& Kelley, 2013).

The woman who anointed Jesus' feet with perfume at Simon's house serves as a biblical example of risk-taking (Matt. 26: 6-13). This act could have resulted in her ostracism from the community. She was criticized by the disciples for her actions, yet Jesus viewed it as a beautiful sacrifice and predicted that her story would be told throughout the course of time.

\section{Proactiveness}

The attempt to lead rather than follow competitors (Miller \& Friesen, 1983) is a mindset that helps to frame the definition of proactiveness. Proactive behavior involves taking the initiative to act, along with experimenting with ideas and anticipating and acting upon future possibilities (Dess et al., 1997; Rauch et al., 2009). This idea of initiative, a tangible action element, is central to the development of innovative behavior within the organization (Dess et al., 1997) and requires leaders to motivate individuals in their span of care toward implementation (Caruana et al, 2002). Proactiveness is a major biblical theme. For example, in the book of Proverbs, the ant illustrates the importance of 
proactiveness as it stores food in summer in preparation for the winter (Prov. 6:6-11). Similarly, in the New Testament, Paul calls for proactive behavior by exhorting Christians to "put on the full armor of God" in preparation for standing firmly during their struggles against spiritual forces of evil (Eph. 6:10-18, NIV).

\section{Church Commitment}

The disruptions caused by the pandemic have caused many church leaders to wonder if their church would come out of the pandemic weakened and diminished once the restrictions are fully removed. It is quite likely that some, if not most churches, will find that some attenders will no longer be participating in church life as they did pre-pandemic, either because they will have lost the habit of going to church or because they will have chosen to start attending other churches. Such changes are a reflection of a person's church commitment, "a Christian's sense of attachment and loyalty to the church that he or she attends most frequently" (Dunaetz, Cullum, and Barron, 2018, p. 126).

Church commitment is important from both a practical and a theological point of view. On a practical (or administrative) level, low church commitment can lead to a person leaving a church which may hurt a church financially and weaken the church's ministries in which the person participated. Theologically and from a spiritual point of view, church commitment is also important. Commitment to the Lord is a central biblical value (Deut. 6:5; Matt 22:37). Such a commitment should be very high, greater than one's commitment to one's family (Luke 14:2627), a commitment held steadfastly and unwaveringly (Luke 9:62). As the church is the body of Christ (Rom. 12:5; I Cor. 3:17), commitment to Christ can be manifested in a commitment to his church. Church commitment can even be considered a visible (but imperfect) proxy for commitment to, and faith in, Christ (James 2:14-26).

In organizational psychology, the commitment an employee has to an organization is known as organizational commitment (Allen \& Meyer, 1990; Cohen, 2013; Meyer \& Allen, 1991) which can be defined as "an employee's sense of attachment and loyalty to the work organization with which the employee is associated" (Cohen, 2013, p. 526). This is conceptually similar to church commitment and variations of organizational commitment scales have been adapted to measure church commitment (Dunaetz \& Bocock, 2020; Dunaetz, Cullum, et al., 2018; Dunaetz et al., 2021). Organizational commitment is important because its consequences include a greater willingness to invest oneself into one's work, higher quality work, greater satisfaction with one's work, and lower 
turnover and absenteeism (Cohen, 2013). In churches, greater church commitment predicts greater ministry involvement of lay people (Dunaetz \& Bocock, 2020).

The antecedents of organizational commitment include shared values with leaders, satisfaction with one's responsibilities, and a desire to maintain relationships with one's coworkers (Cohen, 2013). Among church attenders, tenure (how long a person has attended a church), pastoral humility (vs. pastoral narcissism), and church size (commitment is higher in smaller churches than larger churches) are, at least sometimes, all predictors of church commitment (Dunaetz, Cullum, \& Barron, 2018). Similarly, the degree to which a person shares values with the church predicts church commitment, at least in smaller churches, but to a lesser degree in larger churches (Dunaetz et al., 2021).

This study will examine if, and to what degree, church innovativeness predicts church commitment.

\section{Hypotheses}

Organizational innovativeness in churches may be viewed negatively because of church members' resistance to change. If this is the case, organizational innovativeness will likely predict lower church commitment. Yet organizational innovativeness may be viewed positively because of the greater responsiveness it permits to church members' needs in new contexts. In this case, organizational innovativeness will predict an increase in church commitment. This study will test which of these two attitudes towards innovation has dominated during the COVID-19 pandemic. Thus, the first hypothesis is:

$\mathbf{H}_{\mathbf{1}}$ : Organizational innovativeness in churches will be correlated

to church commitment.

If this exploratory hypothesis is supported, we will be able to determine if church innovativeness has a positive or negative effect on members' commitment to the church.

If church innovativeness impacts church members' commitment to the church, we would also like to know under what conditions this is most likely to be true. Is it more true in small churches than large churches? Is it more true for men than for women? Is there a difference between older church members and younger church members? This study examines whether certain conditions impact the relationship between innovativeness and church commitment. Specifically, we examine the impact of the size of the church, the age of the person providing information about his or her church, how long the person has been attending the church (tenure), and the person's sex. The second hypothesis is thus: 
$\mathbf{H}_{\mathbf{2}}$ : The relationship between organizational innovativeness and church commitment will be moderated by church size, participant's age, participant's tenure, and/or participant's sex.

If this hypothesis is supported, it may provide insight into what types of innovation have been most important during the pandemic. It may also provide clues to the nature of effective ministry in a post-pandemic world.

\section{Method}

In order to test these two hypotheses, an electronic survey was used to collect data during the pandemic from adults who attended evangelical or other protestant churches.

\section{Participants}

Invitations were sent out to members of the first two authors' social networks through social media, email, and texting. Participants were required to be 18 years or older and attend an evangelical or other protestant church. In order to detect correlations of at least $r=.15$ with a statistical power of $80 \%$, the target sample size was 347 participants. However, only 258 participants were able to be recruited. Of these 258 participants, 244 provided usable data; there were 14 participants whose data showed little or no variation in responses indicating that they did not read and respond to the items thoughtfully.

\section{Measures}

After providing their informed consent to participate in the study, participants received a series of items that measured the variables required to test the hypotheses and demographic information.

Church Innovativeness. Based on Ruvio et al.'s (2014) 21-item organizational innovativeness scale, 9 items were chosen which were especially appropriate for churches. These 9 items were modified slightly for church contexts to create the Church Innovativeness Scale (Appendix A). Participants indicated their agreement to each of the items on a 5 -point Likert scale ranging from $1=$ Strongly Disagree to $5=$ Strongly Agree. Sample items include "My church is open and responsive to change" and "The leaders are always seeking new opportunities for the church." Cronbach's (1951) coefficient of reliability for this measure was excellent, $\alpha=.91$.

Church Commitment. Although a participant's church commitment, like organizational commitment, can be measured as a multidimensional construct (Dunaetz, Cullum, et al., 2018; Meyer \& Allen, 
1991), for this study, church commitment was conceptualized as a unidimensional construct focusing on the person's desire to stay or leave the church based on how well the church corresponds to the person's needs and expectations. Based on Bothma and Roodt's (2013) Turnover Intention Scale (TIS-6), items were modified to describe intentions to stay at one's church (Appendix B). Participants indicated their agreement to the six items on a 5 -point Likert scale ranging from $1=$ Strongly Disagree to 5 = Strongly Agree. Sample items include "I often look forward to going to church" and "I often think about finding another church that will better suit my needs" (reverse scored). Cronbach's (1951) coefficient of reliability for this measure was excellent, $\alpha=.89$.

Tenure. The time that a person had been attending his or her church (tenure) was measured with a single question, "How long (in years) have you attended your current church? Enter o if you've attended for less than 6 months." The average tenure of participants was 8.85 years.

Age. The age of participants was measured using a single item asking their age. The average age of participants was 39.40 years.

Gender. Participants indicated their gender with a single item asking their gender. The majority of participants (66.5\%) were female.

Church Size. Participants were asked to indicate how many people attend their church each week and were given a list of 8 choices ranging from "Less than 20" to "More than 2000". The median church size was "201-500".

Race/Ethnicity. Participants were asked to indicate their race or ethnicity if they so desired. Reflecting the Southern California location of the authors, $48.8 \%$ of participants identified as White/Caucasian, 35.3\% as Latino, $5.1 \%$ as Black/African American, and 3.9\% as Asian.

\section{Descriptive Statistics}

\section{Results}

The mean, standard deviation, and range of scores for the variables measured in this study are presented in Table 1. Church innovativeness and church commitment were calculated for each individual by averaging the scores of the items used to measure these constructs (after appropriately unreversing the reverse-scored items; Appendices A and B) so that higher scores indicated higher church innovativeness and greater church commitment. This resulted in scores that could, and indeed did, range from 1.00 to 5.00 with 3.00 as the neutral point. In general, participants saw both their churches' innovativeness $(M=3.51)$ and their commitment to their church $(M=3.70)$ as above the neutral point. 


\begin{tabular}{lccc}
\hline \multicolumn{1}{c}{ Measures } & $M$ & $S D$ & Range \\
\hline Church Innovativeness & 3.51 & 0.88 & $1.00-5.00$ \\
Church Commitment & 3.70 & 0.93 & $1.00-5.00$ \\
Tenure & 8.85 & 8.84 & $0-45$ \\
Church Size & 4.93 & 2.29 & $1-8$ \\
Age & 39.40 & 12.16 & $18-79$ \\
\hline
\end{tabular}

Note: $N=244$.

Table 1. Descriptive Statistics

The table of correlations of the main variables in the study is presented in Table 2. Note that neither church innovativeness nor church commitment were significantly related to the demographics of the participants (tenure, age, gender); perceived church innovativeness and church commitment did not vary between old and young, new members and old-timers, or between men and women. However, they did vary with church size. Larger churches were seen to be more innovative than smaller churches. Moreover, church commitment was higher in large churches rather than in small churches during the pandemic; this is in contrast to a lower level of commitment sometimes seen in larger churches relative to smaller churches (Dunaetz, Cullum, et al., 2018; von der Ruhr \& Daniels, 2012).

\begin{tabular}{|c|c|c|c|c|c|c|}
\hline & 1 & 2 & 3 & 4 & 5 & 6 \\
\hline $\begin{array}{l}\text { 1. Church } \\
\text { Innovativeness }\end{array}$ & -- & & & & & \\
\hline $\begin{array}{l}\text { 2. Church } \\
\text { Commitment }\end{array}$ & $.597^{* * *}$ & -- & & & & \\
\hline 3. Tenure (years) & -.124 & -.065 & -- & & & \\
\hline 4. Church Size & $.134^{*}$ & $.166^{* *}$ & .034 & -- & & \\
\hline 5. Age & .002 & -.008 & $.271^{* * *}$ & -.066 & -- & \\
\hline 6. Gender & .042 & -.039 & .006 & -.126 & .049 & -- \\
\hline
\end{tabular}

Table 2. Correlations of Main Variables 


\section{Hypothesis Testing}

The first hypothesis in this study predicted that church innovativeness would predict church commitment, although the direction of this relationship was not known. This hypothesis was supported, $r(242)=.60$, $p<$.001, two-tailed. Specifically, greater perceived church innovativeness strongly predicted greater church commitment. During the pandemic, innovativeness was viewed very positively; church member's resistance to change does not appear to have affected their church commitment during this period where the felt need for innovation was high.

The second hypothesis predicted that the relationship between church innovativeness and church commitment would be moderated by the demographic characteristics of the participants or their churches. This hypothesis was not supported for participants' tenure, age, or church size. There was no significant difference in this relationship for people of different ages, for people who had attended their church for different periods of time, or for different sized churches; in all these comparisons, the strength of the relationship between church innovativeness and church commitment did not significantly vary ( $p \mathrm{~s}>$.05).

However, there was a significant difference in the relationship between church innovativeness and church commitment when comparing men to women. Gender was a significant moderator of this relationship, $B$ $=.25, S E=.12, t=2.11, p=.036$ (Figure 1). The relationship between innovativeness and church commitment was stronger in women than in men. In churches with high innovativeness, church commitment is high, and women's church commitment is somewhat higher than men's church commitment. However, in churches with low innovativeness, church commitment is low and women's church commitment is much lower than men's church commitment. 


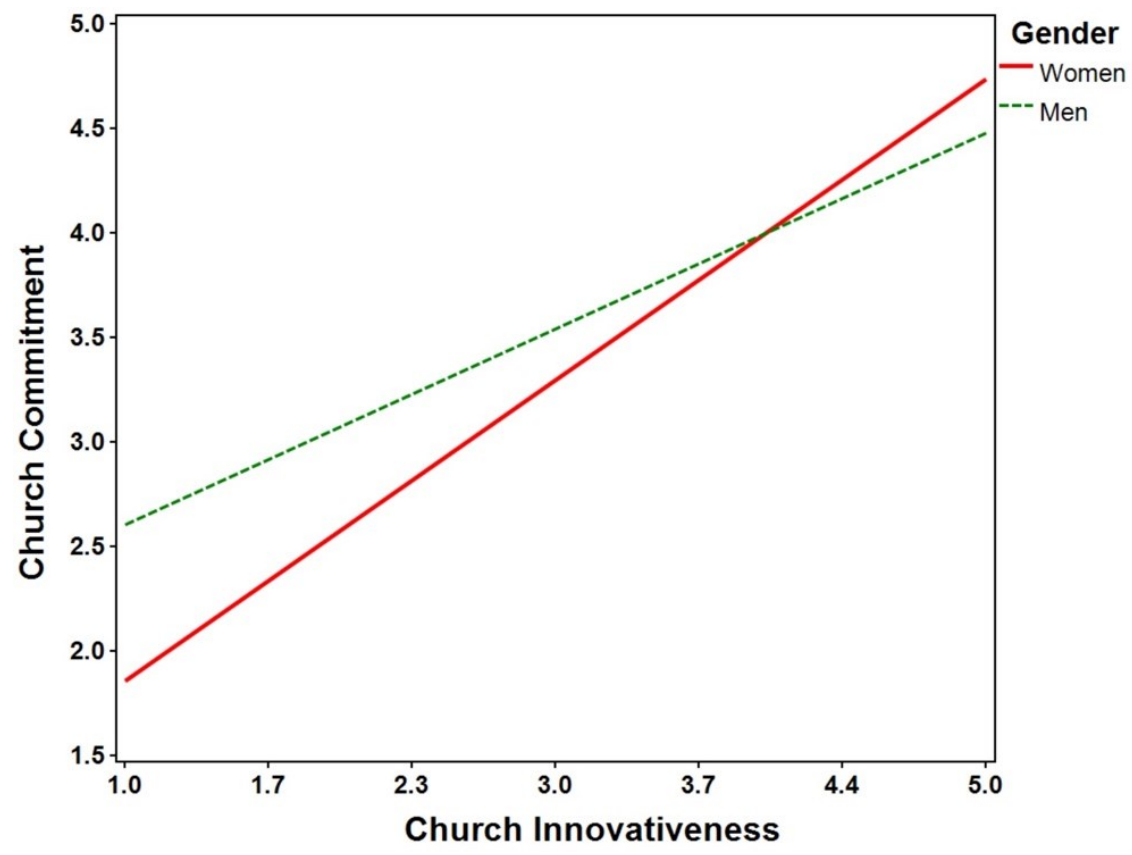

Figure 1. Moderation of the Relationship Between Church Innovativeness and Church Commitment by Gender.

The relationship between church innovativeness and church commitment is significantly stronger in women (solid line) than in men (dotted line) because the line for women has a steeper slope. The difference between men's and women's church commitment is especially noticeable in churches with low innovativeness. Women's church commitment is much lower than men's church commitment in churches that are low in innovativeness.

\section{Discussion}

This study explored whether church innovativeness, defined as the elements of a church's culture that promote innovation (specifically, creativity, organizational openness, future orientation, risk-taking, and proactiveness), was related to church commitment during the COVID-19 pandemic. A very strong positive correlation was found between church innovativeness and church commitment; the more people perceived their church to be innovative, the stronger their commitment was to stay in the church.

This study also examined possible factors (moderators) that would change this relationship. The strength of this relationship did not significantly change with church size, participant age, or participant tenure in the church. It was constant across all these variables. However, it was much stronger for women than for men, suggesting that innovations that responded to women's priorities (relative to men's priorities) were 
especially influential during the pandemic.

\section{The Importance of Innovativeness}

This study provides evidence that innovativeness was very important in keeping people committed to the church during the pandemic. As the aftermath of the pandemic unfolds and North American culture continues to evolve, perhaps faster than ever before, innovativeness is very likely to continue to be important in churches. This means that the elements of organizational culture that are necessary for innovation (creativity, organizational openness, future orientation, risk-taking, and proactiveness) need to be developed and prioritized (Hurley \& Hult, 1998; Ruvio et al., 2014).

Creativity. In organizational contexts, creativity can be viewed as "the creation of a valuable, useful new product, service, idea, procedure, or process" (Woodman et al., 1993, p. 293) when people are working together to achieve goals defined by the organization's mission. During the pandemic, when traditional meetings were no longer possible, new ideas were needed for every type of ministry that contributed to a church's mission, ranging from children's ministry to evangelism, from weddings to funerals.

Some churches were equipped with very creative leaders who came up with many new ideas to respond to the needs. Less creative churches may have chosen to depend on the creativity of other churches and copy what they were doing; this strategy would have undoubtedly been superior to simply making a small number of not-especially creative changes so that the church could function by providing minimal services to its members. Leaders of churches that are members of active church networks (or denominations) were able to share and discuss creative ideas more easily than churches that are not members of such networks.

Organizational Openness. Innovation requires more than creative and useful ideas. The organization needs to be open to these ideas in order to implement them. This requires both adaptability, the ability to adjust programs in order to meet people's needs as the context changes, and flexibility, the willingness to replace existing programs with new ones more appropriate to the present context.

Organizations (e.g., churches) that are led by open-minded people tend to be higher in organizational openness than organizations with less open-minded leaders. People high in the personality trait of openness (one of the Big Five personality traits) tend to be curious, have a willingness to try new ideas, hold unconventional ideas, tolerate ambiguity, and are willing to consider views that differ from their own (DeYoung et al., 2005; 
McCrae, 1996). Moreover, the structure of an organization also influences its openness. In churches with boards that require unanimity before new ideas can be implemented, any board member can block any change, reducing the organizational openness of the church to very low levels. On the other hand, churches where the head pastor or people responsible for specific ministries have the freedom to act as they see fit without seeking approval from others tend to have higher organizational openness. Nevertheless, churches with leaders who have little accountability are ripe for abuse, especially among leaders who are low in humility (Dunaetz, Jung, and Lambert, 2018; Puls, 2020).

Future Orientation. Another element of a church's culture that is essential for innovativeness is a focus on the future. It is all too easy for a church to be focused on what has worked in the past, a conservativism reinforced by evangelical theology which looks at Christ's death as the central point of human history. However, the centrality of Christ's death and resurrection does not mean that human cultures are always the same or that the means by which we communicate the gospel should always be the same; the content of the message is unchanging, but not the forms of communication that we use (Hesselgrave, 1989; Hiebert, 1987; Moreau, 2012).

This means that churches which are looking toward the future to understand how culture is evolving and which have a clear vision of what the church is trying to accomplish will be equipped to adopt the innovations necessary to fulfill the Great Commission in the evolving context. This requires unconventional, out-of-the-box thinking and is closely linked to both creativity and organizational openness.

Risk Taking. A willingness to commit resources to achieve longterm goals is the principal component of risk-taking (Ruvio et al., 2014). This can be expressed through the hiring of new staff people with specialties in technologies and strategies appropriate for the developing environment. But it can also simply mean modifying existing programs to see if the changes create improvements and undoing the changes if they do not. Like organizational openness, risk-taking without accountability can lead to major problems. Accountability means that one may be called to justify one's decisions and behaviors, with appropriate negative consequences if they cannot be justified (Lerner \& Tetlock, 1999). A wise approach for accountability in a church is to have strong negative consequences for decisions and behaviors which violate moral principles, but much lighter (or even no) negative consequences for decisions and behaviors which fail to contribute to a church's mission but do not violate moral principles. This creates an atmosphere where experimenting with 
innovative ideas is safe.

Proactiveness. Rather than simply modifying or adding new programs to a church's ministry to better meet the needs of those influenced by the church, proactiveness requires looking for new opportunities in the external environment of the church and putting them into action. Similar to a missional approach to ministry (Guder, 1998; Stetzer, 2006; Van Rheenen, 2006), proactive churches need to be looking for new opportunities to bring the gospel to people who need it and help them become disciples of Jesus. During the pandemic, such innovations were especially driven by technology during the periods of lock-down.

\section{When was Innovativeness the Most Important?}

In this study, church size, member age, and member tenure did not moderate the relationship between church innovativeness and church commitment; the relationship was equally strong regardless of how these factors varied.

Church Size. Nevertheless, church size was positively correlated with both innovativeness and church commitment. Larger churches (compared to smaller churches) were viewed as more innovative. Several factors might account for this. Larger churches most likely have a history of success and innovation and are less likely to have a gate-keeping structure that resists innovation; they are likely to be higher in organizational openness to change than smaller churches. Moreover, they have the resources to be more innovative and to hire visionary leaders. The importance of this is seen during periods of crisis such as the pandemic. Since members of larger churches are more committed to their churches than members of smaller churches in this study, it appears that larger churches will come out of the pandemic stronger relative to smaller churches. This is an example of "the rich get richer and the poor get poorer" phenomenon that is often the case when technology-based changes are introduced into a context (Dunaetz et al., 2015; Kraut et al., 2002); those who are best equipped (in terms of ability and motivation) to implement a new technology successfully will benefit more from its introduction than those who are less equipped.

Gender. This study found that the relationship between perceived church innovation and church commitment is stronger for women than for men. Why would this be? Certainly, much new technology was introduced into church programs, especially video streaming of services and activities. In general, men are more receptive to technology and more interested in it (Tarafdar et al., 2011). However, the relationship between innovativeness and commitment was weaker in men than in women, indicating that 
something beyond technology was driving church commitment. Technology per se does not seem to be the driving force behind the relationship between perceived church innovativeness and church commitment. We should look toward other gender differences to explain this difference.

Women are more relationship-oriented than men, not in the sense that high-quality close relationships are more important to women than men, but in that social support and community integration are more important to women's psychological well-being than they are to men (Simon, 2002; Umberson et al., 1996). This may very well be the reason for the differences between men and women in the strength of the relationship between church innovativeness and church commitment.

Thus, it is quite possible that the relationship between church innovativeness and church commitment was stronger in women than in men during the pandemic because of women's greater appreciation for innovations which contributed to relationship maintenance and relationship development. This would mean that church commitment would be especially high when innovations were introduced that would enable them to maintain and develop their relationships with other church members; when these innovations were not present, commitment would be lower. This would explain why the relationship between church innovation and church commitment was stronger in women than in men.

Since much of what Christ calls Christians to do, such as loving one another (John 15:12), serving one another (Mark 10:42-45), and making disciples (Matt. 28:18-19), consists essentially of social activities, women's reactions to situations and innovations can provide a measure of how well the church is structured to be able to fulfill this calling. This stronger relationship between innovativeness and commitment in women than men may indicate that churches that provided relationship-oriented innovations more successfully helped people navigate the dangers of isolation and loneliness which threatened their well-being during the pandemic, enabling them to maintain and even develop relationships which are fundamental to the Christian life.

When unable to hold on-campus meetings, many churches introduced Zoom, Facebook livestreaming, or other online video-based apps into their programs. It is likely that some churches retained member commitment more effectively than others because they were able to move the main church activities where social interaction had previously occurred to an online context that maintained these social interactions. This means that churches where fellowship and social interaction occurred mainly in a large group context (such as after a worship service, as may be the case in 
a small church) would have a difficult time maintaining members if they simply started livestreaming worship services. However, in churches where fellowship and social interaction occurred primarily in small groups (as is typical in medium and large churches), successfully moving the small groups to a video chat platform would make maintaining and developing relationships more likely. Such innovations that maintain and develop relationships (rather than the programs) were likely to be the most important innovations that churches could introduce during the pandemic.

\section{Limitations and Future Research}

As is the case with all survey-based research, this study was correlational in nature rather than experimental, which means the direction of causation cannot be determined with certainty; it is possible that high church commitment causes a person to believe that his or her church is more innovative, rather than church innovativeness causing a person to increase in church commitment. However, in most churches, it is likely that the leadership is transparent enough and that the church members are sufficiently aware of the programs to understand where the church stands on the various dimensions of innovativeness. Further studies of church innovativeness, with innovativeness measured by outside, neutral observers, could provide additional evidence for the causal direction. Within individual churches, church leaders can run informal experiments by introducing elements of innovativeness into the church (new programs, vision casting, publicly valuing organizational openness, etc.) and note how people respond within the specific, local context. The introduction of new programs and technology which increase social interaction could also provide evidence for the importance of this type of innovation in a specific church's context.

Similarly, we cannot be sure that the results of this study would be the same in contexts other than that of the COVID-19 pandemic. Further studies in more normal contexts, especially looking at the connections between innovativeness, relationship maintenance and development, and church commitment can provide greater clarity.

\section{Conclusion}

This study has found evidence that innovativeness increased church commitment during the COVID-19 pandemic. It appears that the innovations that strengthened relationships might have been the most important during this period. It is quite possible that this phenomenon will continue to occur in churches after the pandemic. If this is the case, innovativeness will continue to be very important and church leaders 
should strive to increase it through vision casting, leadership selection, developing organizational openness, and especially through introducing new, creative programs and activities that create and solidify relationships between members.

\section{References}

Allen, N. J., \& Meyer, J. P. (1990). The measurement and antecedents of affective, continuance and normative commitment to the organization. Journal of Occupational Psychology, 63(1), 1-18.

Barna, G. (1993). Turn around churches: How to overcome barriers to growth and bring new life to an established church. Regal Books.

Bothma, C. F., \& Roodt, G. (2013). The validation of the turnover intention scale. South African Journal of Human Resource Management, 11(1), 1-12.

Caruana, A., Ewing, M. T., \& Ramaseshan, B. (2002). Effects of some environmental challenges and centralization on the entrepreneurial orientation and performance of public sector entities. Service Industries Journal, 22(2), 43-58.

Choi, S., \& Choi, J.-S. (2014). Dynamics of innovation in nonprofit organizations: The pathways from innovativeness to innovation outcome. Human Service Organizations: Management, Leadership \& Governance, 38(4), 360-373.

Cronbach, L. J. (1951). Coefficient alpha and the internal structure of tests. Psychometrika, 16(3), 297-334.

Dess, G. G., Lumpkin, G. T., \& Covin, J. G. (1997). Entrepreneurial strategy making and firm performance: Tests of contingency and configurational models. Strategic Management Journal, 18(9), 677-695.

DeYoung, C. G., Peterson, J. B., \& Higgins, D. M. (2005). Sources of openness/intellect: Cognitive and neuropsychological correlates of the fifth factor of personality. Journal of Personality, 73, 825-858.

Dunaetz, D. R., \& Bocock, J. (2020). Ministry involvement of church staff and volunteers: The role of organizational commitment and work engagement. Theology of Leadership Journal, 3(1), 52-67.

Dunaetz, D. R., Cullum, M., \& Barron, E. (2018). Church size, pastoral humility, and member characteristics as predictors of church commitment. Theology of Leadership Journal, 1(2), 125-138.

Dunaetz, D. R., Jung, H. L., \& Lambert, S. S. (2018). Do larger churches tolerate pastoral narcissism more than smaller churches? Great Commission Research Journal, 10(1), 69-89.

Dunaetz, D. R., Lisk, T. C., \& Shin, M. (2015). Personality, gender, and age as predictors of media richness preference. Advances in Multimedia, 2015(243980), 1-9.

Dunaetz, D. R., Smyly, C., Fairley, C. M., \& Heykoop, C. (2021). Values congruence and organizational commitment in churches: When do shared values matter? Psychology of Religion and Spirituality, Advance online publication. 
Dykes, W. W. (2018). Play well: Constructing creative confidence with LEGO® SERIOUS PLAY®. Fielding Graduate University.

Ford, C. M. (2002). The futurity of decisions as a facilitator of organizational creativity and change. Journal of Organizational Change Management, 15(6), 635-646.

Garcia, R., \& Calantone, R. (2002). A critical look at technological innovation typology and innovativeness terminology: A literature review. Journal of Product Innovation Management, 19(2), 110-132.

Gavetti, G., \& Levinthal, D. (2000). Looking forward and looking backward: Cognitive and experiential search. Administrative Science Quarterly, 45(1), 113-137.

Guder, D. L. (Ed.). (1998). Missional church: A vision for the sending of the church in North America. William B. Eerdmans Publishing.

Hesselgrave, D. J. (1989). Contextualization: Meanings, methods, and models. Baker Book House.

Hiebert, P. G. (1987). Critical contextualization. International Bulletin of Missionary Research, 11(3), 104-112.

Hult, G. T. M., Hurley, R. F., \& Knight, G. A. (2004). Innovativeness: Its antecedents and impact on business performance. Industrial Marketing Management, 33(5), 429-438.

Hurley, R. F., \& Hult, G. T. M. (1998). Innovation, market orientation, and organizational learning: An integration and empirical examination. Journal of Marketing, 62(3), 42-54.

Hurley, R. F., Hult, G. T. M., \& Knight, G. A. (2005). Innovativeness and capacity to innovate in a complexity of firm-level relationships: A response to Woodside (2004). Industrial Marketing Management, 34(3), 281-283.

Kelley, T., \& Kelley, D. (2013). Creative confidence: Unleashing the creative potential within us all. Crown Publishing.

Kraut, R., Kiesler, S., Boneva, B., Cummings, J., Helgeson, V., \& Crawford, A. (2002). Internet paradox revisited. Journal of Social Issues, 58(1), 49-74.

Lerner, J. S., \& Tetlock, P. E. (1999). Accounting for the effects of accountability. Psychological Bulletin, 125(2), 255-275.

Lumpkin, G. T., \& Dess, G. G. (1996). Clarifying the entrepreneurial orientation construct and linking it to performance. Academy of Management Review, 21(1), 135-172.

McCrae, R. R. (1996). Social consequences of experiential openness. Psychological Bulletin, 120, 323-337.

Meyer, J. P., \& Allen, N. J. (1991). A three-component conceptualization of organizational commitment. Human Resource Management Review, 1, 61-89.

Miller, D., \& Friesen, P. H. (1978). Archetypes of strategy formulation. Management Science, 24(9), 921-933.

Moreau, A. S. (2012). Contextualization in world missions: Mapping and assessing evangelical models. Kregel Publications. 
Neighbour, R. W. (1973). The seven last words of the church: Or "We never tried it that way before". Zondervan Publishing House.

Penfold, G. E., \& Taylor, G. L. (2020). Restart churches: A proven strategy to restore vibrant ministry in your church. ChurchSmart Resources.

Powell, R., Bellamy, J., Sterland, S., Jacka, K., Pepper, M., \& Brady, M. (2012). Enriching church life: A guide to results from National Church Life Surveys for local churches. Mirrabooka Press \& NCLS Research.

Powell, R., \& Pepper, M. (2018). Local churches and innovativeness: An empirical study of 2800 Australian churches. Research in the Social Scientific Study of Religion, 29, 278-301.

Puls, D. (2020). Narcissistic pastors and the making of narcissistic churches. Great Commission Research Journal, 12(1), 67-92.

Rainer, T. S. (2020). The post-quarantine church: Six urgent challenges and opportunities that will determine the future of your congregation. Tyndale Momentum.

Rauch, A., Wiklund, J., Lumpkin, G. T., \& Frese, M. (2009). Entrepreneurial orientation and business performance: An assessment of past research and suggestions for the future. Entrepreneurship Theory and Practice, 33(3), 761-787.

Ruvio, A. A., Shoham, A., Vigoda-Gadot, E., \& Schwabsky, N. (2014). Organizational innovativeness: Construct development and crosscultural validation. Journal of Product Innovation Management, 31(5), 1004-1022.

Salavou, H. (2004). The concept of innovativeness: Should we need to focus? European Journal of Innovation Management, 7(1), 33-44.

Simon, R. W. (2002). Revisiting the relationships among gender, marital status, and mental health. American Journal of Sociology, 107(4), 1065-1096.

Stetzer, E. (2006). The evolution of church growth, church health, and the missional church: An overview of the church growth movement from, and back to, its missional roots. Journal of the American Society for Church Growth, 17(1), 87-112.

Tarafdar, M., Tu, Q., Ragu-Nathan, T. S., \& Ragu-Nathan, B. S. (2011). Crossing to the dark side: Examining creators, outcomes, and inhibitors of technostress. Communications of the Association for Computing Machinery, 54(9), 113-120.

Umberson, D., Chen, M. D., House, J. S., Hopkins, K., \& Slaten, E. (1996). The effect of social relationships on psychological well-being: Are men and women really so different? American Sociological Review, 61(5), 837-857.

Van de Ven, A. H. (1986). Central problems in the management of innovation. Management Science, 32(5), 590-607.

Van Rheenen, G. (2006). Contrasting missional and church growth perspectives. Restoration Quarterly, 48(1), 25-32. 
von der Ruhr, M., \& Daniels, J. P. (2012). Examining megachurch growth: Free riding, fit, and faith. International Journal of Social Economics, 39(5), 357-372.

Wanberg, C. R., \& Banas, J. T. (2000). Predictors and outcomes of openness to changes in a reorganizing workplace. Journal of Applied Psychology, $85(1), 132-142$.

Wang, C. L., \& Ahmed, P. K. (2004). The development and validation of the organisational innovativeness construct using confirmatory factor analysis. European Journal of Innovation Management, 7(4), 303-313.

Whitesel, B. (2020). Growing the post-pandemic church. ChurchLeadership.press. Woodman, R. W., Sawyer, J. E., \& Griffin, R. W. (1993). Toward a theory of organizational creativity. Academy of Management Review, 18(2), 293-321.

\section{Appendix A: Church Innovativeness Scale}

Adapted from Ruvio et al. (2013). The dimensions of innovativeness measured by each item are in parentheses. Participants indicate the level of their agreement with each of the statements.

$$
\begin{aligned}
& 1=\text { Strongly Disagree } \\
& 2=\text { Disagree } \\
& 3=\text { Neither Agree nor Disagree } \\
& 4=\text { Agree } \\
& 5=\text { Strongly Agree }
\end{aligned}
$$

1. My church is constantly looking to develop and offer new or improved ministries. (Creativity)

2. The leaders are encouraged to use original approaches when dealing with problems in church. (Creativity)

3. My church is open and responsive to change. (Openness)

4. The leaders in my church search for fresh, new ways of looking at problems. (Openness)

5 . My church effectively ensures that the leaders and congregation share the same vision of the future. (Future Orientation)

6. My church likes to take big risks. (Risk-Taking)

7. My church does not like to "play it safe." (Risk-Taking)

8. The leaders are always seeking new opportunities for the church. (Proactiveness)

9. The leaders take the initiative in an effort to shape the environment to the church's advantage. (Proactiveness) 


\section{Appendix B: Church Commitment Scale}

Based on Bothma \& Roodt's (2013) Turnover Intention Scale 6 (TI-6)

Participants indicate the level of their agreement with each of the statements.

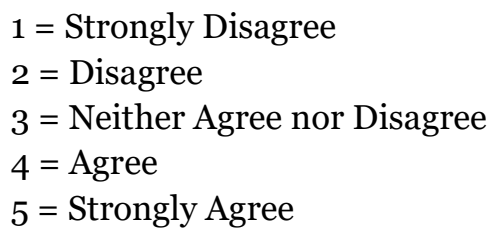

1. I often look forward to going to church.

2. I often think about finding another church that will better suit my needs.* 3. I often consider leaving my church.*

4. My church very much satisfies my personal needs.

5. I am often frustrated in my church because my needs are not met.*

6. I would likely accept an invitation from another church to come visit it.*

Items marked with an asterisk (*) are reversed scored: 5 becomes 1,4 becomes 2, etc.

\section{About the Authors}

Anna Covarrubias graduated with an M.S. in Organizational Psychology from Azusa Pacific University. Her passion is to equip Christian organizations to propel innovation and build healthy cultures.

David R. Dunaetz is Associate Professor of Leadership and Organizational Psychology at Azusa Pacific University, the editor of the Great Commission Research Journal, and formerly a church planter in France.

Wendi Dykes McGehee, PhD, is the Director of the Master of Science in Organizational Psychology at Azusa Pacific University. Her research portfolio centers around creative confidence, play, and innovation. 